\title{
1 Nationalism in a Transnational Age: An Introduction
}

We might believe we live in a postmodern and postnational world. And we might want to believe that a transnational age will secure peace, but the truth is, as political scientist and Princeton University professor Jan-Werner Müller emphasized in 2019, that "[t]here appears to be one indisputable global trend today: the rise of nationalism." ${ }^{11}$ It is also true that regardless of the wish to establish a postnationalist, transnationalist political order that would represent a more global reply to the political issues of the 21 st century, ${ }^{2}$ we, as Andreas Wimmer, another political scientist, worded it, "[w]ith a few exceptions . . . are all nationalists today." ${ }^{3}$ The latter, at the same time, emphasizes that "[n]ationalism provided the answer to the classic boundary question of democracy: Who are the people in whose name the government should rule?"4 It is in particular the power question, or the related fear of people to lose power and status in their existent national order, that makes them fear the impact of changes, as they are representative of the globalization of the economy or increasing migration. ${ }^{5}$ While, for philosopher Kwame Anthony Appiah, "[t]he modern nationstate has always been a community too large for everyone to meet face-to-face; it has always been held together not by literal companionship but by imaginative identification," 6 today, the ingroup-identity resembling the nation is getting related to the fear of the out-group(s) instead of embracing migration as a chance to extend the spiritual principle of the nation to include other, different, and maybe foreign values. ${ }^{7}$

1 Jan-Werner Müller, "False Flags: The Myth of the Nationalist Resurgence," Foreign Affairs 98, no. 2 (2019): 35.

2 Frank Jacob, \#FUCK2020: Impulse zu den Krisen und Herausforderungen des 21. Jahrhunderts (Marburg: Büchner, 2021).

3 Andreas Wimmer, “Why Nationalism Works: And Why It Isn’t Going Away,” Foreign Affairs 98, no. 2 (2019): 28.

4 Ibid., 30.

5 Jürgen Osterhammel, "Nationalism and Globalization," in The Oxford Handbook of the History of Nationalism, ed. John Breuilly, 2nd ed. (Oxford: Oxford University Press, 2016), 694-709.

6 Kwame Anthony Appiah, “The Importance of Elsewhere: In Defense of Cosmopolitanism," Foreign Affairs 98, no. 2 (2019): 26.

7 Michael Thumann, Der neue Nationalismus: Die Wiederkehr einer totgeglaubten Ideologie (Berlin: Die Andere Bibliothek, 2020).

Ә Open Access. (c) 2021 Frank Jacob and Carsten Schapkow, published by De Gruyter. (cc) BY-NC-ND This work is licensed under the Creative Commons Attribution-NonCommercial-NoDerivatives 4.0 International License. https://doi.org/10.1515/9783110729290-001 
When French historian and orientalist Ernest Renan (1823-1892) defined the nation in 1882, he focused on shared pasts and a consensus for the future that would determine its existence in the first place:

A nation is a soul, a spiritual principle. Two things, which in truth are but one, constitute this soul or spiritual principle. One lies in the past, one in the present. One is the possession in common of a rich legacy of memories; the other is present-day consent, the desire to live together, the will to perpetuate the value of the heritage that one has received in an undivided form. Man, Gentlemen, does not improvise. The nation, like the individual, is the culmination of a long past of endeavours, sacrifice, and devotion. Of all cults, that of the ancestors is the most legitimate, for the ancestors have made us what we are. A heroic past, great men, glory (by which I understand genuine glory), this is the social capital upon which one bases a national idea. To have common glories in the past and to have a common will in the present; to have performed great deeds together, to wish to perform still more - these are the essential conditions for being a people. One loves in proportion to the sacrifices to which one has consented, and in proportion to the ills that one has suffered. One loves the house that one has built and that one has handed down. The Spartan song - "We are what you were; we will be what you are" - is, in its simplicity, the abridged hymn of every patrie. ${ }^{8}$

What in today's globalized age, as in moments of national formations of the past, e.g. upheavals against foreign rule, nevertheless still plays an important role in forging the bonds between people is the Other the nation is supposed to be abstracted from. Literary scholar and semiotician Yuri Lotman emphasized this opposition between the $I$ and a culturally different Other in his work Universe of the Mind: A Semiotic Theory of Culture (1990) as well, when he states with regard to literary texts that "The laws of construction of the artistic text are very largely the laws of the construction of culture as a whole. Hence culture itself can be treated both as the sum of the messages circulated by various addressers (for each of them the addressee is 'another', 's/he'), and as one message transmitted by the collective 'I' of humanity to itself. From this point of view human culture is a vast example of autocommunication." ${ }^{9}$ With regard to the creation and communication of the nation, one can also emphasize this self or autocommunication within the group that shares a nation that is communicated in abstraction to a specific Other.

This Other could have been the colonial power that a nationalist movement was directed toward, it could have been the enemy of a war against which the

8 Ernest Renan, “A Lecture Delivered at the Sorbonne, 11 March 1882: 'Qu'est-ce qu'une nation',” in Oeuvres Completes, vol. 1 (Paris: Calmann-Lévy, 1947), 887-907.

9 Yuri Lotman, Universe of the Mind: A Semiotic Theory of Culture, transl. by Ann Shukman (Bloomington: Indiana University Press, 1990), 33. Also see Juri Lotman, Culture and Explosion, transl. by Wilma Clark (Berlin: De Gruyter, 2009), 136. 
national spirit was assembled, but the nation was usually established in countering a different, foreign, and opposite identity. The fact that we are currently facing a tremendous increase in nationalist tensions around the world is therefore without any doubt related to the large numbers of international migrants 260 million were counted by the UN in $2017^{10}$ - who are often considered a threat to the national integrity of a nation state, although the latter is in no real danger. As much as the nation itself is imagined, ${ }^{11}$ so is the menace it is facing from international migration. ${ }^{12}$

The nation, which needs to be abstracted from the idea of homeland that can be the base of an almost romantic idealization, i.e. patriotism, ${ }^{13}$ must be considered as an idea with an implied political meaning and can be changed and redefined by every generation that needs to decide the extent to which the national values of the past are supposed to be the national values of the future. A nation is consequently nothing that is written in stone, although often related to semiotic images and codes, ${ }^{14}$ but something that is in steady transformation. This also means that every generation has to redefine the canon of moral, ethical, cultural, and political standards that have to be applied when forging the new idea of a nation. The United States can serve as an example for this transformation here. While the US nation in 1776 was a white, Christian, male, and unfree one, the one at the end of the 20th century was supposed to be a multicultural, multireligious, human, and free one, although this idea was challenged by the Trump era of recent years that left a fractured and divided US nation. ${ }^{15}$ National divisions within an existent nation state are nothing new if one takes a look into US history in particular, as the Civil War was one between two different national concepts as well. National segregation is a problem nation states could face in the

10 Appiah, “The Importance of Elsewhere," 26.

11 Benedict Anderson, Imagined Communities: Reflections on the Origin and Spread of Nationalism (London: Verso, 1983).

12 Frank Jacob and Adam Luedtke, "Introduction: Migration and the Nation State," in Migration and the Crisis of the Modern Nation State?, ed. Frank Jacob and Adam Luedtke (Wilmington, DE: Vernon Press, 2018), v-xiv.

13 For a theoretical reflection on these differences see, among others, Ivano Cavallini, ed. $\mathrm{Na}$ tion and/or Homeland: Identity in 19th-Century Music and Literature Between Central and Mediterranean Europe (Milano/Udine: Mimesis, 2014).

14 See, among others, Umberto Eco, Inventing the Enemy (Boston: Mariner Books, 2013); Francesco Mangiapane and Tiziana Migliore, eds. Images of Europe: The Union between Federation and Separation (Cham: Springer 2021).

15 Frank Jacob, “Joe Bidens Krux: Die USA und die gespaltene Nation,” November 25, 2020, https://jacobschreibtgeschichteonline.net/2020/11/25/joe-bidens-krux-die-usa-und-die-gespal tene-nation/. 
21st century as well, e.g. with regard to the division of Sudan or to the nationalist independence movements in Catalonia in Spain or Scotland in the UK. It is especially in times of crisis that nationalist emotions gain ground, and the current COVID-19 pandemic seems to have triggered responses that were based on such nationalist feelings. ${ }^{16}$

Nationalism may have intensified, but the pandemic is different from one form of nationalism that determined the nation state-building experience of the "long" 19th century. ${ }^{17}$ In general, it seems appropriate to divide between two different types of nationalism. The first one is a pre-nation state nationalism, a movement to establish a state based on a specific nation that is shared by those who drive the state-building process forward. The second type would then be a post-nation state nationalism, an overexpression of nationalist ambition that could either be directed against an internal minority living in the borders of the nation state or against an external competitor who, due to the necessary accumulation of capital and the securing of resources, becomes an enemy of the nation. ${ }^{18}$ The rivalry of the superpowers in the era of the Cold War overshadowed or even catalyzed these nationalist rivalries into the struggle between two larger political systems. When the conflict was eventually over in the late 1980s and early 1990s, people were willing to believe that this would also mean the end of nationalism or, as American historian Jill Lepore worded it:

The nation-state was in decline, said the wise men of the time. The world had grown global. Why bother to study the nation? Nationalism, an infant in the nineteenth century, had become, in the first half of the twentieth, a monster. But in the second half, it was nearly dead - a stumbling, ghastly wraith, at least outside postcolonial states. And historians seemed to believe that if they stopped studying it, it would die sooner: starved, neglected, and abandoned. ${ }^{19}$

Francis Fukuyama's most important achievement was probably nothing other than explaining to American readers the philosophical ideas of Immanuel Kant (17241804) and Georg Wilhelm Friedrich Hegel (1770-1831) about eternal peace as a

16 Stephan Lesenich, "Corona-Nationalismus: Auch die Solidarität bleibt daheim," in Die Welt nach Corona: Von den Risiken des Kapitalismus, den Nebenwirkungen des Ausnahmezustands und der kommenden Gesellschaft, ed. Dieter F. Bertz (Berlin: Bertz + Fischer, 2021), 143-148.

17 Franz J. Bauer, Das “lange” 19. Jahrhundert (1789-1917): Profil einer Epoche, 4th rev. ed. (Stuttgart: Reclam, 2017).

18 Rosa Luxemburg, Die Akkumulation des Kapitals: Ein Beitrag zur ökonomischen Erklärung des Imperialismus (Berlin: Paul Singer, 1913), https://www.marxists.org/deutsch/archiv/luxem burg/1913/akkkap/index.htm.

19 Jill Lepore, “A New Americanism: Why a Nation Needs a National Story," Foreign Affairs 98, no. 2 (2019): 10. 
consequence of liberal ideas and the end of history, respectively, ${ }^{20}$ and putting them in a modern-day context. Yet while Fukushima was "hardly alone in pronouncing nationalism all but dead," ${ }^{21}$ he was probably the most influential. ${ }^{22}$

Many other academics expected that humanity would reach a political order beyond the nation state, such as Jürgen Habermas, who anticipated a "post-national constellation," 23 or others who regarded the nation to be an outdated concept. ${ }^{24}$ At the same time, the thesis that nationalism has returned since the beginning of the 21st century is somehow misleading, as it had never really disappeared, although the political climate at the end of the 20th century seemed to promise a transnational future instead. ${ }^{25}$ However, nationalism is strong again and might even intensify as a consequence of the present pandemic. Regardless of its rather bad connotation among intellectuals, ${ }^{26}$ the end of the Soviet Union marked the starting point for a new rise of nationalist forces, and "the world has become a world of nation-states governed according to nationalist principles." 27 Wimmer warned readers in 2019 that "[i]n both the developed and the developing world, nationalism is here to stay," 28 and as far as we can presently grasp the impact of the global pandemic, it seems safe to say that he will be right with regard to this evaluation.

The nationalism that has evolved in the last two decades is a new form that not only questions globalization as such but also the wish to live in a more transnational world. ${ }^{29}$ Regardless of the dangers, and as US biologist Robert

20 Immanuel Kant, Zum ewigen Frieden: Ein philosophischer Entwurf, ed. Rudolf Malter (Stuttgart: Reclam, 2008 [1795]); Georg W. F. Hegel, Philosophy of History (New York: Dover, 1956). See also Howard Williams, "The End of History in Hegel and Marx," The European Legacy 2, no. 3 (1997): 557-566.

21 Lepore, “A New Americanism," 10.

22 Francis Fukuyama, The End of History and the Last Man (New York: Free Press, 1992).

23 Jürgen Habermas, Die postnationale Konstellation: Politische Essays (Berlin: Suhrkamp, 1998).

24 Ulrike Guérot, “Wir brauchen die Nation nicht mehr," Der Standard, May 2, 2017, https:// www.derstandard.at/story/2000056814520/politologin-guerot-wir-brauchen-die-nation-nichtmehr, cited in Sina Arnold, Sebastian Bischoff and Jana König, "Postnationale Potenziale: Praktiken jenseits der Nation,” Aus Politik und Zeitgeschichte 68, no. 48 (2018): 2. A survey of the discussion is provided by Arnold et al. as well.

25 Christian Geulen, "Zur 'Wiederkehr' des Nationalismus," Aus Politik und Zeitgeschichte 68, no. 48 (2018): 4.

26 Wimmer, "Why Nationalism Works," 27.

27 Ibid., 28.

28 Ibid., 34.

29 Colin Crouch, “Der Nationalismus globalisiert sich,” ZEIT Online, February 11, 2017, http:// www.zeit.de/wirtschaft/2017-02/globalisierung-widerstand-rechte-nationalismus-donaldtrump-marine-le-pen-is/komplettansicht. 
Sapolsky correctly remarked, "[t]oday, this toxic brand of nationalism is making a comeback across the globe, spurred on by political leaders eager to exploit it for electoral advantage." 30 The rise of nationalism, however, not only happened in accordance with a crisis of our global age, but also because it was used in a variation, namely "nationalist populism." 31 Political leaders of right-wing movements and state leaders like Donald Trump, Vladimir Putin, and Recep Tayyip Erdoğan used people's concerns and anxieties in their countries to pave their own way to power, applying the "political business model is permanent culture war" 32 to represent a "very loud minority" 33 that fears to lose its own social standing within society and considers it threatened by transnational forces or an increase of progressive liberalism, democratic socialism, or other "menaces" like global migration. Through their political strategies, the new nationalists threaten the future of transnational visions like the European Union, which is still suffering from its primary forms of affiliation, i.e. the nation state. ${ }^{34}$

It was skepticism over Europe that made British Prime Minister Theresa May explain in October 2016 that "if you believe you are a citizen of the world, you are a citizen of nowhere." 35 And her successor Boris Johnson noticeably continued to intensify the nationalist emotions toward the final Brexit, leaving Britain alone in a time of crisis and facing new pro-European separatist nationalism within. While true Europeans in the sense of the word tried to defend a union based on values and a federation the different nations would find a new identity in, the nationalist ambitions in the respective nation states prevented a re-formulation of the single nations according to such a plan. ${ }^{36}$

Anti-European skepticism was also stimulated by the so-called "refugee crisis," which gave populist right-wing movements fodder for their anti-liberal cannons and a narrative to channel the fear and anxiety of people who felt a loss of status to be imminent and thereby to gain considerable support in many countries. ${ }^{37} \mathrm{New}$

30 Robert Sapolsky, “This Is Your Brain on Nationalism,” Foreign Affairs 98, no. 2 (2019): 47.

31 Müller, "False Flags," 35.

32 Ibid., 36.

33 Ibid., 38.

34 Geulen, "Zur 'Wiederkehr'," 8.

35 Appiah, “The Importance of Elsewhere," 20.

36 Bruno Latour, Down to Earth: Politics in the New Climatic Regime (Cambridge: Polity Press, 2018), 99-107.

37 Crouch, "Der Nationalismus globalisiert sich.” See also Martin Sabrow, "Höcke und wir," Zeitgeschichte-online, January 25, 2017, http://www.zeitgeschichte-online.de/kommentar/ hoecke-und-wir. 
“politicians”"38 like Trump, Viktor Orbán, and others would use these fears, the rejection of a progressive democracy and its representatives also in the media, i.e. the "establishment," the rejection of an economic globalization that caused job losses for national economies, and the rejection of immigration in order to change the cultural demographics of a country. ${ }^{39}$ The new political leaders that represent neo-nationalism, no matter if we call it Trumpism, ${ }^{40}$ Orbánism, ${ }^{41}$ or neo-Ottomanism, ${ }^{42}$ in some way also represent a form of Orwellian "brute authoritarianism" steadily contesting facts and representing alternative narratives to history and contemporary issues alike. ${ }^{43}$ Older national narratives not only in these authoritarian regimes but also in totalitarian ones, i.e. China and Russia, are replaced with new ones that put their focus on blood, faith - in the political or religious sense -, and heritage instead of moral values and solidary ethics. ${ }^{44}$ The language they use for their claims is very different from what people expected from politicians in the past, but this is also what makes the populist nationalists so appealing for a loud group of supporters: "These men all constantly joke about private parts, fucking and shitting, often partnered with boasts about excessive screwing, eating and drinking. Their bawdy lingo tells us more about their political strategy and strengths than any manifesto: populism and penis jokes go hand in hand."45

38 Trump in particular argued that he was not a politician but a successful businessman, and always claimed he would "drain the swamp" of the political capital. Adam Soboczynski, "Donald Trump: 'Wir werden unsere Nation mit amerikanischen Händen wieder aufbauen', Die Zeit 5 (2017), January 26, 2017, http://www.zeit.de/2017/05/donald-trump-politische-kommuni kation-rhetorik-sprache/komplettansicht.

39 Such views were often backed by populist authors. As an example, among others, see Ann Coulter, Adios, America: The Left's Plan to Turn Our Country into a Third World Hellhole (Washington, DC: Regnery Publishing, 2016). On the impact of such books in the American context, see Nicole Hemmer, Messengers of the Right: Conservative Media and the Transformation of American Politics (Philadelphia: University of Pennsylvania Press, 2016).

40 Regula Stämpfli, Trumpism: Ein Phänomen verändert die Welt (Basel: Münsterverlag, 2018). 41 Krisztina Koenen, “Orbánismus in Ungarn Ursprünge und Elemente der 'Illiberalen Demokratie',” Osteuropa 65, no. 11-12 (2015): 33-44.

42 Alexander Murinson, Turkish Foreign Policy in the 21st Century: Neo-Ottomanism and the Strategic Depth Doctrine (London: I. B. Tauris, 2020); M. Hakan Yavuz, Nostalgia for the Empire: The Politics of Neo-Ottomanism (Oxford: Oxford University Press, 2020).

43 Adam Gopnik, “Orwell's '1984' and Trump's America,” The New Yorker, January 27, 2017, https://www.newyorker.com/news/daily-comment/orwells-1984-and-trumps-america.

44 Soboczynski, "Donald Trump." See also Adam Gopnik, "Trump’s Radical Anti-Americanism,” The New Yorker, February 13-20, 2017, https://www.newyorker.com/magazine/2017/02/ 13/trumps-radical-anti-americanism.

45 Peter Pomerantsev, “The False Lords of Misrule,” Granta 137, January 20, 2017, https:// granta.com/false-lords-misrule/. 
To think that nationalism is a historical phenomenon we will not have to bother about in a few years or decades is wishful thinking. To quote Lepore once more:

The endurance of nationalism proves that there's never any shortage of blackguards willing to prop up people's sense of themselves and their destiny with a tissue of myths and prophecies, prejudices and hatreds, or to empty out old rubbish bags full of festering resentments and calls to violence. . . . A nation founded on revolution and universal rights will forever struggle against chaos and the forces of particularism. A nation born in contradiction will forever fight over the meaning of its history. ${ }^{46}$

The present book, which assembles the extended papers that were presented at an international workshop at Nord Universitet, Norway - co-organized with the Center for the Study of Nationalism in the College of International Studies at the University of Oklahoma, USA - in November 2019, intends to address the problems nationalism causes in an age that was considered to be transnational already. It will analyze different national contexts and narratives to show which role nationalism still plays and which negative impacts the abuse of it by the populist nationalists of our time could create.

The first section aims to provide a closer look at the continuities of older nationalist narratives and their reframing in a more global 21st century. Frank Jacob opens the section with a discussion of the continuities and discontinuities of Turkish nationalism since the end of the First World War. He evaluates the role of Kemal Atatürk in the formation of the Turkish nation after the War of Independence (1918-1922) and how this national narrative is contested nowadays by neo-Ottomanism. Jacob's chapter highlights in what ways nationalisms can change and which events or factors determine these changes over a longer time period. The following chapter by Sven Brajer and Johannes Schütz follows a similar approach and offers a longue durée survey of East German nationalism, highlighting the continuities and transformations from the Imperial period until today and argues that the end of the Soviet Union forced not only formerly peripheral regions to redefine their idea of the nation ${ }^{47}$ but also Russia to reinvent its nation and thereby to apply a reinterpretation of the past. Alicja Curanovićs chapter focuses on the "phantomic nature of missionary nationalism" and its consequences for Russian politics and shows the extent to which the history of the pre-revolutionary Russian Empire is revived as a national narrative to

46 Lepore, “A New Americanism,” 11, 19.

47 Ivan Krastev, After Europe (Philadelphia: University of Pennsylvania Press, 2017). See also Irene Götz, Klaus Roth and Marketa Spiritova, eds., Neuer Nationalismus im östlichen Europa: Kulturwissenschaftliche Perspektiven (Bielefeld: Transcript, 2017). 
sanction Putin's expansionist policy. The last chapter in this section by James Okolie-Osemene switches to another geographical context and shows how far nationalism is limiting a "new transnational Pan-Africanism," highlighting one of the problems the African continent is facing as well and thereby stressing that the fight between nationalist and transnationalist ideas is truly a global conflict and not a purely Western and post-industrial one.

The second section takes the question of identity and the role of the Other in its creation into closer consideration. Inessa Kouteinikova shows how photographs were used to create a "symbology of nationhood" in the Russian context, especially with regard to the depiction and perception of Central Asia. That there can exist, as mentioned before, different national identities in one nation state that might come into conflict with each other is then presented via a case study about Georgia by Irakli Chkhaidze. National identities are, however, not only contested in the 21st century but also communicated, especially by using social media. This aspect is discussed in the third chapter in this section, a Pakistani case study by Muhammad A. Z. Mughal, who analyzes the role of new media for the national narratives shared by a new generation of women and men in Pakistan.

The final section of the book examines nationalisms in a global context, meaning that nationalisms can be embedded into larger global narratives or movements but are then torn between this globalizing process and the national frontiers within it. First, Tetiana Perga provides a study about eco-nationalism in Ukraine in the late 1980s and early 1990s that shows how nationalist ideas were a side-product of a transnational protest movement of the time. Anna Zadora's case study of Belarus also points out the nationalist limitations of globalization, as she discusses the conflict "between globalization and authoritarian confinement, between Europe and Russia," a conflict that has even been more intensified by the revolutionary process in Belarus, where the future of the nation state has still not yet been decided. People will continue to struggle there, as well in other national contexts, to find out if they are open enough to reach a transnational order of living or if they are too fearful to leave the comforting environment of their own nation.

\section{Works Cited}

Anderson, Benedict. Imagined Communities: Reflections on the Origin and Spread of Nationalism. London: Verso, 1983.

Appiah, Kwame Anthony. "The Importance of Elsewhere: In Defense of Cosmopolitanism." Foreign Affairs 98, no. 2 (2019): 20-26. 
Arnold, Sina, Sebastian Bischoff and Jana König. “Postnationale Potenziale: Praktiken jenseits der Nation.” Aus Politik und Zeitgeschichte 68, no. 48 (2018): 27-33.

Bauer, Franz J. Das “lange” 19. Jahrhundert (1789-1917): Profil einer Epoche. 4th rev. ed. Stuttgart: Reclam, 2017.

Cavallini, Ivano, ed. Nation and/or Homeland: Identity in 19th-Century Music and Literature Between Central and Mediterranean Europe. Milano/Udine: Mimesis, 2014.

Coulter, Ann. Adios, America: The Left's Plan to Turn Our Country into a Third World Hellhole. Washington, DC: Regnery Publishing, 2016.

Crouch, Colin. "Der Nationalismus globalisiert sich.” ZEIT Online, February 11, 2017. http:// www.zeit.de/wirtschaft/2017-02/globalisierung-widerstand-rechte-nationalismus-don ald-trump-marine-le-pen-is/komplettansicht.

Eco, Umberto. Inventing the Enemy. Boston: Mariner Books, 2013.

Fukuyama, Francis. The End of History and the Last Man. New York: Free Press, 1992.

Geulen, Christian. “Zur 'Wiederkehr' des Nationalismus." Aus Politik und Zeitgeschichte 68, no. 48 (2018): 4-8.

Gopnik, Adam. “Orwell's '1984' and Trump's America.” The New Yorker, January 27, 2017. https://www.newyorker.com/news/daily-comment/orwells-1984-and-trumps-america.

Gopnik, Adam. “Trump's Radical Anti-Americanism.” The New Yorker, February 13-20, 2017. https://www.newyorker.com/magazine/2017/02/13/trumps-radical-anti-americanism.

Götz, Irene, Klaus Roth and Marketa Spiritova, eds. Neuer Nationalismus im östlichen Europa: Kulturwissenschaftliche Perspektiven. Bielefeld: Transcript, 2017.

Guérot, Ulrike. “Wir brauchen die Nation nicht mehr.” Der Standard, May 2, 2017. https:// www.derstandard.at/story/2000056814520/politologin-guerot-wir-brauchen-die-nationnicht-mehr.

Habermas, Jürgen. Die postnationale Konstellation: Politische Essays. Berlin: Suhrkamp, 1998. Hegel, Georg W. F. Philosophy of History. New York: Dover, 1956.

Hemmer, Nicole. Messengers of the Right: Conservative Media and the Transformation of American Politics. Philadelphia: University of Pennsylvania Press, 2016.

Jacob, Frank and Adam Luedtke. "Introduction: Migration and the Nation State." In Migration and the Crisis of the Modern Nation State?, edited by Frank Jacob and Adam Luedtke, v-xiv. Wilmington, DE: Vernon Press, 2018.

Jacob, Frank. “Joe Bidens Krux: Die USA und die gespaltene Nation.” November 25, 2020. https://jacobschreibtgeschichteonline.net/2020/11/25/joe-bidens-krux-die-usa-und-diegespaltene-nation/.

Jacob, Frank. Impulse zu den Krisen und Herausforderungen des 21. Jahrhunderts. Marburg: Büchner, 2021.

Kant, Immanuel. Zum ewigen Frieden: Ein philosophischer Entwurf, edited by Rudolf Malter. Stuttgart: Reclam, 2008 [1795].

Koenen, Krisztina. "Orbánismus in Ungarn Ursprünge und Elemente der 'Illiberalen Demokratie'." Osteuropa 65, no. 11-12 (2015): 33-44.

Krastev, Ivan. After Europe. Philadelphia: University of Pennsylvania Press, 2017.

Latour, Bruno. Down to Earth: Politics in the New Climatic Regime. Cambridge: Polity Press, 2018.

Lepore, Jill. “A New Americanism: Why a Nation Needs a National Story." Foreign Affairs 98, no. 2 (2019): 10-19.

Lesenich, Stephan. “Corona-Nationalismus: Auch die Solidarität bleibt daheim.” In Die Welt nach Corona: Von den Risiken des Kapitalismus, den Nebenwirkungen des 
Ausnahmezustands und der kommenden Gesellschaft, edited by Dieter F. Bertz, 143-148. Berlin: Bertz + Fischer, 2021.

Lotman, Juri. Culture and Explosion, transl. by Wilma Clark. Berlin: De Gruyter, 2009.

Lotman, Yuri. Universe of the Mind: A Semiotic Theory of Culture, transl. by Ann Shukman. Bloomington: Indiana University Press, 1990.

Luxemburg, Rosa. Die Akkumulation des Kapitals: Ein Beitrag zur ökonomischen Erklärung des Imperialismus. Berlin: Paul Singer, 1913. https://www.marxists.org/deutsch/archiv/lux emburg/1913/akkkap/index.htm.

Mangiapane, Francesco and Tiziana Migliore, eds. Images of Europe: The Union between Federation and Separation. Cham: Springer 2021.

Müller, Jan-Werner. “False Flags: The Myth of the Nationalist Resurgence.” Foreign Affairs 98, no. 2 (2019): 35-41.

Murinson, Alexander. Turkish Foreign Policy in the 21st Century: Neo-Ottomanism and the Strategic Depth Doctrine. London: I. B. Tauris, 2020.

Osterhammel, Jürgen. "Nationalism and Globalization." In The Oxford Handbook of the History of Nationalism, 2nd ed., edited by John Breuilly, 694-709. Oxford: Oxford University Press, 2016.

Pomerantsev, Peter. “The False Lords of Misrule.” Granta 137, January 20, 2017. https:// granta.com/false-lords-misrule/.

Renan, Ernest. “A Lecture Delivered at the Sorbonne, 11 March 1882: 'Qu'est-ce qu’une nation'.” In Oeuvres Completes, vol. 1, 887-907. Paris: Calmann-Lévy, 1947.

Sabrow, Martin. "Höcke und wir." Zeitgeschichte-online, January 25, 2017. http://www.zeitge schichte-online.de/kommentar/hoecke-und-wir.

Sapolsky, Robert. “This Is Your Brain on Nationalism." Foreign Affairs 98, no. 2 (2019): 42-47.

Soboczynski, Adam. "Donald Trump: 'Wir werden unsere Nation mit amerikanischen Händen wieder aufbauen'," Die Zeit 5, January 26, 2017. http://www.zeit.de/2017/05/donaldtrump-politische-kommunikation-rhetorik-sprache/komplettansicht.

Stämpfli, Regula. Trumpism: Ein Phänomen verändert die Welt. Basel: Münsterverlag, 2018.

Thumann, Michael. Der neue Nationalismus: Die Wiederkehr einer totgeglaubten Ideologie. Berlin: Die Andere Bibliothek, 2020.

Williams, Howard. "The End of History in Hegel and Marx." The European Legacy 2, no. 3 (1997): 557-566.

Wimmer, Andreas. “Why Nationalism Works: And Why It Isn’t Going Away." Foreign Affairs 98, no. 2 (2019): 27-34.

Yavuz, M. Hakan. Nostalgia for the Empire: The Politics of Neo-Ottomanism. Oxford: Oxford University Press, 2020. 
